\title{
BEREBUT KUASA RUMAH TUHAN: EKSPANSI IDEOLOGI RADIKAL MELALUI MASJID DI KOTA BEKASI
}

\author{
Zulfan Taufik \\ Prodi Aqidah dan Filsafat Islam, Fakultas Usbuluddin, Adab dan Dakwah, LAIN Bukittinggi \\ E-mail: zulfantaufik@gmail.com
}

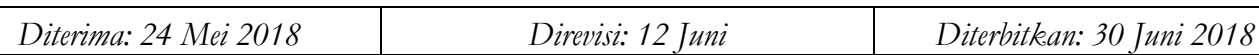

\begin{abstract}
Democracy in Indonesia which was formed as a result of reforms has opened up a large space for religious groups to voice their political and ideological aspirations. Mosques, as a center of community activity, have also become the arena for the contestation of various religious groups in the sowing and dissemination of their ideology. This paper focuses on capturing the phenomenon of the spread of radical Islamic ideology in Bekasi, West Java through mosques. specifically, this paper examines two mosques based on the initial survey indicated to have been influenced by groups supporting ISIS as their unit of analysis; How is the mode of expansion and strategy of the radical group in influencing the DKM of the mosque. Knowledge of the results of this research, which can cover up the fact that there is a lack of adequate knowledge about the mode of expansion and strategy of the movements of the radical groups has made them influential even though in a limited number of mosques. By making two mosques in Bekasi City as a case study, this paper finds various variables such as environmental situations and conducive transfer of cognition, religious material content, and DKM administrators and lecturers who have a radical ideological perspective that have implications for the dissemination of ideology which fits the group. In other words, a mosque as a religious base of society is one of the strategic places for religious groups to spread their ideology.
\end{abstract}

Keywords: mosque, religious ideology, radicalism, Bekasi City.

\section{Abstrak}

Demokrasi di Indonesia yang terbentuk sebagai hasil reformasi, telah membuka ruang besar bagi kelompok-kelompok keagamaan untuk menyuarakan aspirasi politik dan ideologi mereka. Masjid, sebagai pusat aktivitas masyarakat, pun menjadi arena kontestasi berbagai kelompok keagamaan dalam penyemaian dan penyebaran ideologi mereka. Tulisan ini fokus untuk menangkap fenomena persebaran ideologi Islam radikal di Bekasi Jawa Barat melalui masjid. secara khusus, tulisan ini mengkaji dua masjid yang berdasarkan survey awal terindikasi telah dimasuki kelompok yang mendukung ISIS sebagai unit analisisnya; Bagaimana modus ekspansi dan strategi kelompok radikal tersebut dalam mempengaruhi DKM masjid. Pengetahuan akan hasil penelitian ini, nantinya dapat menutupi fakta tentang kurangnya pengetahuan yang memadai tentang modus ekspansi dan strategi gerakan kelompok radikal tersebut telah membuat mereka berpengaruh meskipun dalam jumlah terbatas di beberapa masjid. Dengan menjadikan dua masjid yang ada di Kota Bekasi sebagai studi kasusnya, tulisan ini menemukan berbagai variabel seperti situasi lingkungan dan transfer kognisi yang kondusif, muatan materi keagamaan, serta pengurus DKM dan penceramah yang memili-ki perspektif ideologi radikal memberikan implikasi dalam penyebaran ide $\neg$ ologi yang sesuai dengan kelompoknya. Dengan kata lain, masjid sebagai basis keagamaan masyarakat menjadi salah satu wadah strategis bagi kelompok keagamaan untuk menyebarkan ideologi mereka.

Kata Kunci: masjid, ideologi keagamaan, radikalisme, Kota Bekasi.

\section{Latar Belakang}

Reformasi yang terbentuk pasca-Orde Baru, sebagaimana kesimpulan yang umum diterima, telah membuka ruang yang besar bagi gerakan keagamaan dalam memproliferasi aspirasi politik dan ideologi mereka. Tidak mengherankan bila kemudian ruang besar yang tercipta tersebut menjadi arena kontestasi 
beragam aspirasi politik dan ideologi tersebut. Perubahan kontur politik inilah yang kemudian banyak mengubah citra Islam Indonesia dan anggapan tentang Muslim Indonesia yang sebelumnya dikenal dengan "wajah senyum" toleran dan cenderung kompromi, menjadi "wajah marah" yang penuh konflik.

Gejala "wajah marah" Islam yang muncul tersebut mengandung variasi dan kompleksitas, yang oleh para ahli disederhanakan dengan memberi beberapa label, seperti: radikal, ekstrem, fundamentalisme, Islamisme, dan militan. ${ }^{2}$ Term radikal digunakan dalam tulisan ini dengan pertimbangan bahwa istilah tersebut telah umum digunakan dalam diskursus akademis di Indonesia.

Radikalisme agama yang berlangsung ekstensif sejak tumbangnya rezim Orde Baru tersebut ditandai dengan kemunculan berbagai kelompok Islam garis keras di era reformasi ini. Sebut saja Laskar Jihad, Majelis Mujahidin Indonesia (MMI), Front Pembela Islam (FPI), Hizbut Tahrir Indonesia (HTI), dan beberapa kelompok lainnya. Beberapa karakteristik

${ }^{1}$ Lebih jelasnya, lihat Martin van Bruinessen, Contemporary Developments in Indonesian Islam: Explaining the "Conservative Turn" (Singapore: ISEAS, 2013), 21-53. Bandingkan dengan Felix Heiduk, "Between a Rock and a Hard Place: Radical Islam in Post-Suharto Indonesia", International Journal of Conflict and Violence, Vol. 6, No. 1, 2012, h. 26-40; Quinton Temby, "Imagining an Islamic State in Indonesia: From Darul Islam to Jemaah Islamiyah", Indonesia, Vol. 89, 2010, h. 1-36; Greg Fealy, "Islamic Radicalism in Indonesia: The Faltering Revival?", Southeast Asian Affairs, 2004, h. 104-121; Zulfan Taufik, "Youth, Tarekat, and Religious Deradicalization in Indonesia: The Activism of Mahasiswa Ahlith Thariqah Al Mu'tabarah An Nahdliyyah (MATAN)", Proceeding The $9^{\text {th }}$ International Graduate School and Scholars' Conference in Indonesia (Yogyakarta: Sekolah Pascasarjana UGM, 2017), h. 693710 .

${ }^{2}$ Tidak ada istilah tunggal dan dapat disepakati oleh para pengkaji mengenai kelompok garis keras tersebut. Lihat, Ridwan al-Makassary, dkk., Benih-benih Islam Radikal di Masjid: Studi Kasus Jakarta dan Solo (Jakarta: CSRC UIN Syarif Hidayatullah Jakarta, 2010), h. 3; Roxanne L. Euben, Enemy in the Mirror Islamic Fundamentalism and the Limits of Modern Rationalism (Princeton: Princeton University Press 1999), h. 17. utama kelompok-kelompok yang dikategorikan sebagai radikal tesebut terletak pada orientasi salafisme (orientasi pada masa lalu) yang kuat dan keterpengaruhan oleh ulama-ulama Timur Tengah yang dipercayai sebagai pandangan dunia Islam yang paling absah. ${ }^{3}$

Belakangan, dalam beberapa kasus mutakhir, gerakan radikal ini menggunakan masjid sebagai media dalam penyemaian dan penyebaran ideologi mereka. Sebagaimana yang diendus dan disikapi tegas oleh Nahdlatul Ulama (NU) dan Muhammadiyah, sebagai organisasi masa Islam moderat terbesar di Indonesia, dengan cara membentengi masjidmasjid mereka dari beragam upaya penyusupan dan pengambilalihan oleh kelmpok-kelompok radikal. ${ }^{4}$ Indikasi penggunaan masjid sebagai wadah penyebaran ideologi radikal, telah juga ditunjukkan oleh penelitian Center for The Study of Religion and Culture (CSRC) UIN Syarif Hidayatullah Jakarta yang mengangkat tema tentang pemetaan ideologi masjid di

3 Penjelasan mengenai penggunaan istilah radikal dan sejarah pertumbuhan ormas radikal di Indonesia, lihat Martin van Bruinessen, "Genealogies of Islamic Radicalism in Post-Suharto Indonesia", South East Asia Research, Vol. 10, No. 2, 2002, h. 117-154; Muhammad Sirozi, "The Intellectual Roots of Islamic Radicalism in Indonesia: Ja'far Umar Thalib of Laskar Jihad (Jihad Fighter) and His Educational Background", The Muslim World, Vol. 95, No. 1, 2005, h. 81-120; Syafwan Rozi, "Dari Islam Radikal ke Islam Pluralis: Geneologi Gerakan Paderi dan Pengaruhnya terhadap Islam Pluralis di Perbatasan Minangkabau", Masyarakat Indonesia, Vol. 41, No. 1, 2015, h. 15-27; Donny Syofyan, "Some Notes on Religious Radicalization and Terrorism in Indonesia", Islam Realitas: Journal of Islamic and Social Studies, Vol. 2, No. 2, 2016, h. 134-145.

4 Pada bulan Oktober 2007 PBNU menyelenggarakan Babtsul Masa'il di Pondok Pesantren Zainul Hasan Genggong Probolinggo Jawa Timur. Hal penting yang menjadi rekomendasi dalam pertemuan tersebut adalah pentingnya mensertifikasi masjid-masjid NU demi mencegah infiltrasi kelompok-kelompok radikal. Adapun PP. Muhammadiyah menerbitkan Surat Keputusan Pimpinan Pusat (SKPP) No. 149/Desember 2006, yang intinya adalah untuk menjaga amal usaha Muhammadiyah (masjid, sekolah, panti asuhan, rumah sakit, universitas) agar tidak disusupi atau diambil alih oleh kelompok radikal yang memiliki ideologi/paham berbeda dengan Muhammadiyah sebagai ormas Islam moderat. 
Jakarta dan Solo pada rentang tahun 20082009. ${ }^{5}$

Dibandingkan dengan penelitian CSRC pada rentang 2008-2009 yang menunjukkan bahwa gerakan radikal masih belum secara terbuka mengekspresikan ideologinya di masjid, kasus yang terjadi di Bekasi para tahun 2014 menunjukkan derajat yang meningkat. Gerakan radikal yang terindikasi berasal dari kelompok Jama'ah Anshorut Tauhid (JAT) Kota Bekasi pimpinan Syamsuddin Uba, telah berani mendeklarasikan dukungan kepada organisasi Islamis State of Iraq and Syiria (ISIS) yang dilakukan di Masjid Muhammad Ramadhan dan Masjid Al-Muhajirin, PekayonBekasi. Bahkan Komunitas Intelijen Daerah (Kominda) Kota Bekasi mencatat sedikitnya delapan masjid di wilayah itu dijadikan tempat kegiatan menyebarkan ideologi kelompok ISIS. $^{6}$

Berulangnya kasus kekerasan terhadap kelompok minoritas, turut membuat Bekasi menjadi salah satu daerah di Indonesia yang menjadi pusat perhatian. Paralel dengan itu, Bekasi juga menjadi arena bagi tumbuhnya dua kekuatan keagamaan konservatif, baik di kalangan Islam maupun Kristen. Beberapa kelompok Kristen konservatif memandang Bekasi dengan masyarakat urbannya yang berlimpah sebagai target potensial, sementara kelompok-kelompok Islam garis keras melihat peluang yang sama dengan perspektif yang berbeda yaitu Bekasi sebagai basis mobilisasi massa Muslim untuk menguatkan pengaruh dan perannya yang lebih besar di wilayah

${ }^{5}$ Kedua hasil penelitian tersebut, disatukan dalam buku Ridwan al-Makassary, dkk., Benih-benih Islam Radikal di Masjï: Studi Kasus Jakarta dan Solo (Jakarta: CSRC UIN Syarif Hidayatullah Jakarta, 2010).

${ }^{6} \mathrm{http}: / /$ metro.tempo.co/read/news/2014/08/0 7/064597826/delapan-masjid-di-bekasi-diduga-

kemasukan-isis;

http://nasional.sindonews.com/read/888364/14/duku ngan-kepada-isis-muncul-di-bekasi-1407236192; http://news.liputan6.com/read/2087060/polisibenarkan-ada-deklarasi-isis-di-masjid-al-muhajirinbekasi. Diakses pada 1 Desember 2015. tersebut. Di antara organisasi-organisasi Islam di Bekasi yang aktif dalam berbagai upaya protes pembangunan rumah ibadah di Bekasi adalah Dewan Dakwah Islamiyah Indonesia (DDII), Gerakan Pemuda Islam (GPI), Front Pembela Islam (FPI), dan Jama'ah Anshorut Tauhid (JAT). ${ }^{7}$

Sebagai wilayah urban dan penyangga penyangga Ibukota Jakarta yang menjadi salah satu tujuan utama migrasi dari berbagai wilayah di Indonesia, ${ }^{8}$ dapat dikatakan bahwa kemunculan organisasi-organisasi keagamaan yang mengusung mental kewaspadaan terhadap agama lain di Bekasi, merupakan "imbasan" dari Jakarta. Jarak geografis yang relatif dekat dari ibukota, membuat Bekasi menjadi tempat strategis dan membuat dinamika kehidupan keagamaan di Bekasi menjadi sangat dinamis. Sehingga muncul berbagai anggapan bahwa kekisruhan yang terjadi di Bekasi sering tidak dilakukan oleh warga Bekasi sendiri, melainkan dilakukan oleh rombongan dari luar Bekasi. ${ }^{9}$ Selain itu, meskipun mayoritas penduduk Bekasi adalah Muslim, bertambahnya warga pendatang yang berlatar belakang agama dan etnis berbeda terus bertambah. Dinamika ini meneguhkan bahwa isu agama, tepatnya

${ }^{7}$ Marthen Tahun, Budi Asyhari-Afwan, dan Tim Data Center CRCS, Monograf Jawa Barat: Demografi Agama di Jawa Barat dan Anotasi Bibliografi (Work in Progress, 2015), h. 5.

${ }^{8}$ Kota Bekasi tergolong sebagai wilayah yang padat penduduknya. Pada tahun 2008 Jumlah Penduduk Kota Bekasi 1.793.924. Sampai dengan tahun 2014 jumlah penduduk Kota Bekasi telah mencapai 2.382.689. Dengan demikian, selama kurun waktu 6 tahun pertumbuhan penduduk Kota Bekasi mencapai 23,71 persen. Seiring dengan makin banyaknya pemukiman baru di Kota Bekasi dan bertambahnya pendatang baru, maka bertambah semarak pula suasana kehidupan beragama di Kota Bekasi. Oleh karena itu, kerukunan beragama menjadi isu penting di dalam pelaksanaan pembangunan di Kota Bekasi. Pemerintah Kota Bekasi, Informasi Laporan Penyelenggaraan Pemerintahan Daerah Kota Bekasi Tahun 2014.

${ }^{9}$ Mohammad Iqbal Ahnaf, dkk. Politik Lokal dan Konflik Keagamaan: Pilkeada dan Struktur Kesempatan Politik. dalam Konflik Keagamaan di Sampang, Bekasi, dan Kupang (Yogyakarta: Center for Religious and Cross-cultural Studies/CRCS UGM, 2015), h. 34. 
intoleransi agama, makin menguat di Kota Bekasi.

Ditempatkan dalam konteks di atas, penelitian ini fokus untuk memotret fenomena persebaran ideologi Islam radikal di Bekasi Jawa Barat, yang secara khusus menempatkan masjid yang berdasarkan survey awal terindikasi dimasuki kelompok yang mendukung ISIS, sebagai unit analisisnya. Oleh karena itu, penting untuk dikaji modus operandi ideologi dan strategi gerakan kelompok radikal tersebut dalam mempengaruhi DKM masjid. Pengetahuan akan hasil penelitian ini, nantinya dapat menutupi fakta tentang kurangnya pengetahuan yang memadai tentang modus ekspansi dan strategi gerakan kelompok radikal tersebut, telah membuat mereka berpengaruh meskipun dalam jumlah terbatas di beberapa masjid. Selain itu, kurangnya pengetahuan yang memadai tentang kontestasi antara kelompok radikal dan non-radikal di lingkup masjid, dapat diasumsikan membuat advokasi kebebasan beragama di Bekasi cenderung tidak terarah, salah sasaran, dan kurang mampu memperluas cakupan aliansi (karena kurang memahami peta kontestasi di lapagan).

Artikel ini berbasis penelitian lapangan (fieldwork) dan data pustaka (library research). Sumber data utama penelitian ini adalah hasil wawancara mendalam (indepth interview), focused group discussion (FGD), dokumentasi, dan observasi terlibat (participant observation) di dua masjid yang telah ditentukan secara purposif ${ }^{10}$, pada bulan Oktober-November tahun 2016

${ }^{10}$ Perkembangan dan persebaran tempat ibadah kaum Muslim di Kota Bekasi terbilang pesat. Menurut catatan resmi Badan Pusat Statistik Bekasi, hingga tahun 2015 sebanyak 1.142 bangunan masjid dan 1.645 mushala/langgar telah berdiri di atas tanah seluas 21.049 ha ${ }^{10}$ tersebut. Dikatakan pesat karena pada tahun 2014, Kota Bekasi baru memiliki 950 bangunan masjid dan 1.470 mushalla/langgar. Artinya, sebanyak 192 bangunan masjid dan 175 mushala/langgar telah dibangun dalam kurun waktu satu tahun. Lihat, IPDS BPS Kota Bekasi, Bekasi dalam Angka 2016 (Badan Pusat Statistik Kota Bekasi, 2016), h. 131. lalu. Kedua masjid tersebut adalah: Masjid Muhammad Ramadhan dan Masjid Nurul Islam (Islamic Centre) Kota Bekasi. Secara keseluruhan penelitian, demi pencapaian pemahaman yang integratif-interkonektif, peneliti menggunakan paradigma kualitatif dengan pendekatan fenomenologis.

\section{Masjid sebagai Wadah Kontestasi Ideologi}

Secara etimologis, masjid berasal dari kata dalam bahasa Arab yang menunjukkan tempat (Zaraf makēann) yang berarti tempat sujud. Menurut al-Zamakhsyari, sebagaimana dikutip al-Qahtani, "Karena sujud merupakan rangkaian salat yang paling mulia, mengingat betapa dekatnya seorang hamba dengan Tuhannya ketika sujud, maka tempat tersebut dinamakan masjid dan tidak marka' (tempat ruku)." Sementara dalam makna terminologisnya, masjid adalah tempat para hamba melakukan segala aktivitas, baik yang bersifat vertikal maupun horizontal, dalam rangka beribadah kepada Allah Swt."

Dengan pengertiannya sebagaimana di atas, maka dapat dikatakan bahwa secara umum masjid memiliki dua fungsi utama: Pertama, sebagai tempat ibadah yang bersifat ritual; dan kedua, sebagai tempat segala kegiatan yang berdimensi sosial-kemasyarakatan sesama anggota masyarakat Muslim yang berada di lokasi sekita masjid. Karena pada hakikatnya, beragam kegiatan sosial-kemasyarakatn tersebut juga sesungguhnya merupakan bentuk ibadah kepada Allah Swt.

Dalam sejarah perkembangan Islam, masjid merupakan salah satu pilar penting yang tidak hanya berfungsi sebagai tempat ibadah ritual, melainkan juga memiliki fungsi dalam berbagai aspek kehidupan sosial. Dengan kata lain, fungsi masjid terus tumbuh melampaui dimensi keagamaan seiring dengan perkembangan Islam. Dalam berbagai riwayat,

${ }^{11}$ Ādil Muḥammad Darwīsh, Al-Masjid fĩ al-Islām wa Risālatubu fĩ al-Mujtama' al-Mu'āṣir (Kairo: Dār al'Ilm, 1996), h. 1-2. 
dengan mudah dapat ditemukan berbagai cerita tentang bagaimana masjid pada masa-masa awal perkembangan Islam bersifat multifungsi. ${ }^{12}$

Dalam catatan Quraish Shihab, tidak kurang dari sepuluh peran yang diemban oleh Masjid Nabawi pada masa-masa awal perkembangan Islam, yakni sebagai: 1) pusat ibadah seperti salat dan zikir, 2) tempat konsultasi dan komunikasi persoalan ekonomi dan sosial-budaya, 3) tempat pendidikan, 4) tempat santunan sosial, 5) tempat latihan militer dan persiapan alat-alatnya, 6) tempat pengobatan korban perang, 7) tempat perdamaian dan pengadilan sengketa, 8) aula dan tempat menerima tamu, 9) tempat menawan tawanan perang, 10) pusat penerangan/informasi atau pembelaan agama. ${ }^{13}$ Gambaran tentang beragam fungsi masjid pada masa awal Islam tersebut, menunjukkan bahwa syiar Islam yang meliputi aspek ukhrawi maupun duniawi; spiritual dan material, dimulai dari masjid.

Konsekuensi dari fungsinya yang beragam tersebut, membuat masjid lekat dengan perkembangan sosial dan politik. Pada masa kekuasaan dinasi dan kerajaan Islam misalnya, masjid pernah dijadikan sebagai pusat politik penguasanya. Dalam banyak kasus, para sultan atau khalifah memanfaatkan masjid untuk memantapkan dominasi dan kepentingan kekuasaannya. Karena itu, ketika terjadi persaingan politik antara kelompok Abbasiyah dan Umayyah, atau antara Sunni dan Syiah, masjid secara langsung maupun tidak langsung menjadi media propaganda yang paling efektif. Khutbah Jum'at menjadi forum yag dianggap efektif, dimana seorang khatib

12 Tidak mengherankan jika banyak dikatakan bahwa masjid merupakan pusat peradaban Islam dimulai. Lihat, Anik Farida, dkk., Transformasi Sosial Masjid dalam Pusaran Peradaban (Jakarta: Balai Litbang Agama Jakarta, 2013), h. 1.

${ }^{13}$ Lihat Quraish Shihab, Membumikan al-Qur'an (Bandung: Mizan, 1999), h. 426. dengan leluasa memuji khalifah yang berkuasa dan sekaligus menghujat lawan politik mereka.

Pendirian masjid oleh masyarakat tatkala dominasi suatu dinasti atau pemerintah melemah, tidak juga serta-merta berarti bahwa politisasi di masjid kemudian hilang, tetapi kecenderungan dominasinya berpindah ke kelompok-kelompok sosial keagamaan dan politik. Kemunculan ragam ideologi keagamaan, mazhab fikih, serta kecenderungan politik tertentu, membuat masjid pun muncul dengan corak dan orientasi ideologi-politk yang beragam. ${ }^{14}$ Misalnya saja adanya penyebutan masjid NU, masjid Muhammadiyah, masjid Ahmadiyah, masjid Syiah, masjid Wahabi, dan lain sebagainya. ${ }^{15}$

Tidak terkecuali ideologi radikal yang turut disebarkan melalui masjid oleh organisasi keagamaan pengusungnya. Seperti terjadinya konflik politik yang sangat keras di Pakistan, masjid menjadi salah satu wadah proliferasi kelompok radikal. Lal Masjid (Masjid Merah) yang notabene adalah masjid pemerintah, berubah menjadi markas gerakan radikal yang secara terbuka mendukung kelompok Taliban. Di masjid ini pulalah, pemberlakukan syariat Islam diumumkan dan terjadinya krisis berdarah ketika pemerintah berupaya merebut masjid tersebut dari kelompok radikal. ${ }^{16}$

Narasi sebagaimana di atas, pada realitasnya tidak terjadi hanya di negara atau komunitas yang mayoritas berpenduduk Muslim. Riset Quinton Wiktorowicz yang

${ }^{14}$ Ridwan al-Makassary, dkk., Benih-benih Islam Radikal di Masjid, 44.

15 Kecenderungan politisasi masjid oleh kelompok sosial-keagamaan tertentu, bukan merupakan hal baru. Karena memang, keterhubungan antara politik dan masjid telah eksis sejak masa Nabi Saw. Lebih jelasnya, lihat Abbasali Farahati, "The Mosque as the First Political-Ideological Base in the Islamic Society", Journal of Politics and Law 4, No. 1 (2011): 146-152. Bandingkan dengan Agus Sunaryo, "Masjid dan Ideologisasi Radikalisme Islam: Menyoal Peran Masjid sebagai Media Transformasi Ideologi", Akademika, Vol. 22, No. 1, 2017, h. 225-248.

${ }^{16}$ Ridwan al-Makassary, dkk., Benih-benih Islam Radikal di Masjid, h. 45. 
tentang perkembangan gerakan Islam radikal di Barat, menyimpulkan bahwa masjid yang terbuka terhadap berbagai kelompok dan aktivitas sosial keagamaan, sangat rentan dimasuki oleh kelompok-kelompok radikal. Di Perancis, misalnya, otoritas berwenangnya telah menutup setidaknya empat masjid di wilayah Paris karena digunakan untuk menyebarkan ideologi radikal. Perancis yang masih memberlakukan status darurat akibat berbagai serangan teroris. ${ }^{17}$

\section{Performa Islam di Urban Bekasi}

Kota Bekasi tergolong sebagai wilayah yang padat penduduknya. Pada tahun 2008, penduduk Kota Bekasi berjumlah 1.793.924. Sampai dengan tahun 2014, jumlah penduduk Kota Bekasi telah mencapai 2.382.689. Dengan demikian, selama kurun waktu 6 tahun pertumbuhan penduduk Kota Bekasi mencapai 23,71 persen. Pertambahan dan pertumbuhan penduduk baik secara alami maupun migrasi membawa pengaruh yang sangat besar terhadap perkembangan kota. Namun harus diakui secara empirik bahwa pertambahan penduduk kota, terutama dari arus pendatang, menimbulkan permasalahan baru yang cukup kompleks baik fisik maupun non fisik. Kota Bekasi yang pada awalnya berfungsi sebagai wilayah penyangga, kemudian meningkat menjadi wilayah penyeimbang DKI Jakarta sebagai Ibukota Negara Republik Indonesia. ${ }^{18}$

Sebagai kota yang sedang berkembang dengan pesat, Bekasi cukup menjanjikan bagi para investor yang membuka banyak peluang lapangan kerja. Sehingga orang dari berbagai latar belakang etnis dan agama berbondongbondong datang untuk mencari penghidupan di Bekasi. Sejak masa kolonial Belanda, Bekasi

${ }^{17}$ Lebih jelasnya lihat, Quinton Wiktorowicz, Radical Islam Rising: Muslim Extremism in the West (Lanham: Rowman and Littlefield Publishers, 2005).

18 Pemerintah Kota Bekasi, Informasi Laporan Penyelenggaraan Pemerintahan Daerah Kota Bekasi Tabun 2014 (Pemerintah Kota Bekasi, Tahun Anggaran 2015), h. $10-11$. dikenal sebagai wilayah sub-urban dengan kesuburan tanah dan melimpahnya hasil bumi. Tidak mengherankan bila sejak dahulu di Bekasi telah menarik para pendatang dari luar Bekasi seperti Bali, Melayu, Bugis, Jawa, Cina, Arab, dan lain-lain untuk bermigrasi dan bermukim di Bekasi. Dengan kedatangan berbagai unsur budaya itulah, Bekasi pun mulai mendapat pengaruh dari unsur-unsur budaya lain. $^{19}$

Kehadiran agama Islam juga memiliki kontribusi yang besar terhadap kebudayaan Bekasi yang memang menjadi agama mayoritas di sana. Dalam catatan sejarah, Islam telah masuk dan menyebar di wilayah Bekasi sejak abad ke-16 yang dibawa oleh para pengikut Fatahillah di antaranya adalah dua orang keturunan Sultan Abdul Fatah Banten bernama K.H. Kandong di Kampung Jati Keramat, Desa Jatibening dan RH Shohoh di Desa Jakasampurna, Bekasi Selatan. ${ }^{20}$ Sejak saat itu, nuansa keislaman sangat kental dalam kehidupan sehari-hari masyarakat Bekasi.

Berdasarkan data BPS, Kota Bekasi dalam Angka 2016, jumlah penduduk Muslim di Kota Bekasi mencapai 2.141 .407 (86,99\%) dari total 2.461.393 orang. Berturut-turut jumlah penduduk agama lain berdasarkan tingkat persentasenya adalah sebagai berikut: Kristen 195.985 (7,9\%), Katolik 71.770 (2,9\%), Hindu 27.952 (1,1\%), Buddha 22.492 (0,9 \%), Konghuchu 201 (0,008 \%), dan Aliran Kepercayaan $1.586(0,06 \%){ }^{21}$

Seiring dengan makin banyaknya pemukiman baru di Kota Bekasi dan bertambahnya pendatang baru, maka bertambah semarak pula suasana kehidupan

${ }^{19}$ Andi Sopandi, Sejarah dan Budaya Kota Bekasi: Sebuah Catatan Perkembangan Sejarah dan Budaya Masyarakat Bekasi (Bekasi: Dinas Olahraga, Kebudayaan, dan Kepariwisataan Pemerintah Bekasi, 2009), h. 182185.

${ }^{20}$ Harun Alrasyid, dkk., Bekasi dari Masa ke Masa (Badan Pemberdaya Masyarakat Kabupaten Bekasi, 2006), h. 5 .

${ }^{21}$ Badan Pusat Statistik, Kota Bekasi dalam Angka 2016 (Bekasi: BPS Kota Bekasi, 2016), h. 42. 
beragama di Kota Bekasi. Oleh karena itu, kerukunan beragama menjadi isu penting di dalam pelaksanaan pembangunan di Kota Bekasi. Terkait isu-isu kerukunan umat beragama, sepanjang Tahun 2014 terdapat beberapa kasus kerukunan beragama yang berkembang. Kasus tersebut antara lain, kasus pendirian Gereja Stanislaus Cosca di Kalamiring, Permasalahan pendirian beberapa Gereja di Kavling Mangseng, dan sarana/prasarana tembat ibadah yang digunakan HKBP Ciketing masa izinnya telah habis.

Selain isu yang disebabkan permasalahan pendirian rumah ibadah, kerukunan beragama juga terganggu oleh isu berkembangnya gerakan radikal di wilayah Kecamatan Bekasi Selatan dan Bekasi Timur, serta penangkapan tersangka teroris di Kelurahan Margahayu. Salah satu upaya Pemerintah Kota Bekasi melalui Badan Kesbangpol dalam menjaga kerukunan beragama adalah dengan memaksimalkan peran Forum Kerukunan Umat Beragama (FKUB) dan Forum Pembauran Kebangsaan (FPK). Keberadaan kedua forum ini memiliki nilai strategis dalam memelihara kerukunan melalui penyelesaian kasus-kasus keagamaan antarumat beragama di Kota Bekasi. Selain itu, Pemerintah Kota Bekasi melalui Badan Kesbangpol melakukan tindakan preventif. Upaya preventif yang telah dilakukan Pemerintah Kota Bekasi melalui Badan Kesbangpol Kota Bekasi adalah dengan mengadakan dialog mendalam diantara pemuka agama.

Selain itu, usaha preventif juga dilakukan dalam bentuk sosialisasi, fasilitasi, pembinaan, dan pemantauan. Terkait isu kerukunan beragama, Badan Kesbangpol melaksanakan Fasilitasi Forum Kerukunan Umat Beragama (FKUB). Kegiatan ini bertujuan memberikan fasilitasi kepada upaya FKUB dalam mewujudkan kenyamanan dalam kehidupan antarumat beragama di Kota Bekasi. Badan Kesbangpol juga melaksanakan pembinaan
Forum Pembauran Kebangsaan (FPK). Tujuan dari kegiatan ini adalah mendayagunakan FPK untuk meningkatkan upaya pembauran di masyarakat. Pembauran kebangsaan di masyarakat merupakan salah satu cara dalam upaya meningkatkan kerukunan beragama di Kota Bekasi.

Badan Kesbangpol juga melaksanakan giat pemantauan. Pemantauan berfungsi untuk menjaring informasi dan mendeteksi permasalahan kerukunan beragama yang terjadi di masyarakat. Dengan adanya pemantauan, cegah dini terkait dampak yang dimunculkan permasalahan kerukunan beragama dapat dilaksanakan. Pada Tahun 2014, upaya pemantauan ini terwujud dalam bentuk kegiatan Pelatihan Kewaspadaan Dini dan Manajemen Konflik, Penyelenggaraan Kominda, serta Pemantauan dan Pengawasan Orang Asing. Upaya lain yang dilakukan adalah dengan memperkuat peran dan fungsi dari forum bentukan pemerintah yang memiliki hubungan kerja di dalam kerukunan umat beragama, dalam hal ini FKUB dan FPK. Dari laporan Pemerintah Kota Bekasi, beragam kejadian yang menggerus kerukunan umat beragama di Kota Bekasi, disebabkan oleh beberapa faktor berikut: pendirian rumah ibadah, penistaan ajaran agama dari kelompok tertentu dan perselisihan yang terjadi di internal pengurus rumah ibadah. Adapun upaya penanganan yang dilakukan oleh pemerintah terkait gerakan radikal adalah melakukan fasilitasi pergantian pengurus DKM dari masjid-masjid yang diduga terdapat pergerakan radikal. $^{22}$

Adapun dalam perkembangan kolompok-kelompok keagamaan Islam di Bekasi, dapat dipolakan menjadi tiga bagian: Pertama, kelompok Islam moderat seperti NU, Muhammadiyah, Jam'iyautul Al-Washliyah,

22 Pemerintah Kota Bekasi, Informasi Laporan Penyelenggaraan Pemerintahan Daerah Kota Bekasi Tabun 2014 (Pemerintah Kota Bekasi, Tahun Anggaran 2015), h. 10-11. 
Mathlaul Anwar, Persis, Perti, PUI, Ittihadul Muballighin, dan lainnya yang tergolong pro demokrasi. Kedua, kelompok Islam radikalis, yang diidentifikasi memiliki pemikiran atau gagasan bahkan tindakan radikal seperti: Jamaah Ansharut Tauhid (JAT), Hizbut Tahrir Indonesia (HTI), Khilafatul Muslimin, dan Front Pembela Islam (FPI). Ketiga, kelompok Islam minoritas yang "dianggap sesat", seperti kelompok kecil penganut faham Syi'ah dan Ahmadiyah, serta LDII yang kemudian mengubah paradigma keagamaan pada pemahaman dan sikap yang lebih mengarah kepada kelompok Islam moderat.

\section{Ekspansi Ideologi Radikal di Masjid Bekasi \\ - Masjid Muhammad Ramadhan: JAT, ISIS, dan Intervensi Pemkot}

Masjid Muhammad Ramadhan berlokasi di wilayah pemukiman elit Taman Galaxy, tepatnya di Jalan Pulo Ribung, Kel. Pekayon Jaya Kec. Bekasi Selatan Kota Bekasi. Masjid ini berdiri di tanah yang merupakan Fasum (fasilitas umum) dan Fasos (fasilitas sosial) seluas $1000 \mathrm{~m}^{2}$ (dari yang sebelumnya diajukan seluas $3.500 \mathrm{~m}^{2}$ ). Masjid ini dibangun mulai tahun 2002 sampai tahun 2004. Sumber utama anggaran pembangunan masjid, berasal dari wakaf seseorang yang bernama Ali Harharah sebesar 2,4 milyar rupiah. Adapun dari sumbangn masyarakat, diperoleh dana sebesar 400 juta rupiah.

Atas dasar pemberian dana wakaf tersebut, wakif (Ali Harhaharah) meminta kepada panitia pembangunan masjid agar nama masjid dinisbatkan kepada anaknya yang baru meninggal, yakni Muhammad Ramdhan. Inilah asal usul penamaan masjid menjadi Masjid Muhammad Ramadhan. ${ }^{23}$

Setelah pembangunan masjid telah rampung, pengelolaan Masjid diserahkan secara resmi oleh pemerintah Bekasi melalui Bupati

${ }^{23}$ Wawancara dengan Pak Ananto, Pengurus Yayasan Al-Anshor, 2 November 2016.
Nonon Sontani kepada panitia pembangun Masjid yang lantas membentuk Dewan Kemakmuran Masjid (DKM) pada tahun 2004. Susunan kepengurusan DKM Masjid yang terbentuk saat itu diisi oleh Nanang Prayudyanto sebagai Ketua Umum DKM, dengan Dewan Syuranya adalah Syuhada Bahri, Sukandar Gozali, Salimin Dhani, dan lain-lain. Pata tahun 2007, sekitar tiga tahun setelah Masjid berdiri, Ali Harharah kembali memberi wakaf bangunan gedung pendidikan. Demi memanfaatkan adanya gedung pendidikan tersebut, maka muncullah gagasan untuk sebuah yayasan, yang kemudian diberi nama Yayasan Al-Anshor.

Berdasarkan keterangan Nanang, ia sebelumnya juga merupakan pengurus Yayasan Al-Anshor, yakni sebagai bendahara. Namun karena adanya rangkap jabatan dalam pengelolaan DKM dan Yayasan, maka ia pun mundur dari jabatannya di Yayasan Al-Anshor. Jadi, menurut Nanang, DKM Masjid berstatus otonom alias tidak berada di bawah kepengurusan Yayasan. Karena dalam sejarahnya, DKM sudah terlebih dahulu eksis sebelum adanya Yayasan. ${ }^{24}$ Setelah adanya Yayasan Al-Anshor, beberapa Dewan Syuro DKM ditarik menjadi Dewan Pembina Yayasan Al-Anshor. Seperti Syuhada Bahri, Salimin Dhani, dan Sukandar Gozali. Posisi kosong di DKM kemudian diisi oleh para ustaz Salafi seperti Abu Jibril dan Farid Okbah.

Adanya dualisme kepengurusan di Masjid tersebut membuat adanya tarik-menarik kepentingan dalam pengelolaan masjid. Pengurus Yayasan berkali-kali hendak menarik DKM ke bawah kepengurusan Yayasan, tetapi selalu gagal karena ditentang oleh pengurus DKM. Bahkan Nanang, sebagai Ketua DKM, selalu bersikeras menolak diganti sebagai Ketua

24 Nanang Prayudyanto, Ketua Dewan Kemakmuran Masjid Muhammad Ramadhan 2004$2014 . \quad$ Lihat http://www.voaislam.id/read/liberalism/2014/04/23/29995/buntutkisruh-masjid-m-ramadhan-bekasi-majelis-talim-ngajidi-parkiran/ (Diakses pada 28 November 2016). 
ketika Yayasan berusaha membuat regenerasi dan pergantian kepengurusan sejak tahun 2009, dengan argumen bahwa DKM Masjid berstatus otonom, tidak berada di bawah Yayasan AlAnshor.

Sukandar Gozali (Ketua DKM pengganti Nanang) mengatakan bahwa belakangan sejak tahun 2009, Nanang mulai berubah orientasi ideologi pemikirannya karena dipengaruhi oleh ajaran-ajaran Jama'ah Ansharut Tauhid (JAT) yang dipelopori oleh Abu Bakar Ba'asyir. Akibatnya, kegiatan-kegiatan yang diselenggarakan oleh DKM dinilai cenderung eksklusif dan membuat resah warga sekitar. Sebagaimana dikatakan Sukendar Gozali, "Kami sudah lama menasehati dan berkali-kali mengingatkan. Tapi tetap tak ada perubahan. Beberapa kali dicoba untuk melakukan pergantian DKM juga selalu ditentang. Pak Nanang beranggapan DKM Masjid tidak di bawah Yayasan Al-Anshor. Begitu terus berulang-ulang. Maka Pemkot mengambil alih DKM dan mengadakan pergantian DKM dan saya mendapat amanah menjadi Ketua DKM.,"25

Memang, pada masa kepengurusan DKM lama di bawah kepemimpinan Nanang Prayudyanto, Masjid Muhammad Ramadhan sangat populer di kalangan aktivis Islam yang sering menggelorakan dakwah tauhid dan jihad. Kegiatan pengajian dan aktivitas sosial masjid ini juga cukup populer di wilayah Jabodetabek bahkan luar Jawa. H. Suratman, selaku Ketua Bidang Sosial dan Kemasyarakatan mengatakaan: "Masjid ini kan dulunya sering ada kegiatan rutin bedah buku yang dilakukan jamaah luar. Mereka juga mengundang pembicara dari luar. Dan kegiatan itu dapat suntikan dana yang luar biasa besar dari pihak luar. Untuk antisipasi masjid dikuasai orang

${ }^{25}$ Keterangan Sukandar Ghozali, Ketua DKM yang ditunjuk Pemkot Bekasi setelah proses pengambilalihan. Lebih jelasnya lihat http://www.muslimedianews.com/2014/04/alhamdulil lah-masjid-muhammad-ramadhan.html, (Diakses pada 20 November 2016). luar apalagi kelompok ISIS, kami akan perketat izin kegiatan di sini". ${ }^{26}$ Pendapat serupa dikatakan Dahlan, salah seorang pengurus Masjid Muhammad Ramadhan lainnya, "Kajian di masjid ini memang berbeda, tema-tema luas soal konflik agama di luar. Abu Bakar Ba'asyir sebelum ditangkap, dulu sering memimpin kajian itu. Nah, mungkin karena itu ada anggapan negatif soal masjid ini. Puncaknya kemarin warga protes". 27

Sebagai contoh, salah satu tema kegiatan bedah buku yang diadakan DKM Masjid Muhammad Ramadhan yang bekerjasama dengan JAT pimpinan Abu Bakar Ba'asyir adalah sebagaimana pengumuman yang tercantum di salah satu website berikut: ${ }^{28}$

Hadirilah Bedah Buku Agama Demokrasi, Terbitan: Kafayeh Cipta Media

Karya: Al-Allamah Asy-Syaikh Al-Mujahid Abu Muhammad 'Ashim Al-Maqdisi Hafidzhullah

Hari/Tgl: Ahad, 5 April '09 Jam.09.00 s/d Selesai

bersama: Al-Ustadz Halawi Ma'mun, Lc, MA Hafidrababulloh

(Ketua Dewan Syuro' Jama'ah Anshorut Tauhid (JAT))

Al-Ustadz KH Abu Bakar Ba'asyir Hafidzhabulloh

(Amir (Pimpinan) Jama'ah Anshorut Tauhid (JAT))

bertempat di: Masjid Muhammad Ramadhan, Jln. Pulo Ribung Raya

Taman Galaxi, Samping Polsek Bekasi Selatan, Kota Bekasi Contact Person: Bpk. Pai. 081311321978

Penyelengara: DKM. Muhammad Ramadhan, Bekasi Keriasama dengan IAT

Pada puncaknya, Masjid Muhammad Ramadhan ini menjadi sorotan masyarakat sekitar, berbagai Ormas Islam, serta pemerintah dan kepolisian, setelah JAT yang difasilitasi oleh DKM Masjid mendeklarasikan dukungan terhadap ISIS (Islamic State of Iraq and Suriah) pada 15 Fabuari 2014 lalu di masjid ini. Sebagaimana dikatakan oleh Wahidin Hanbali, "15 hari setelah mereka deklarasikan

26 Wawancara dengan H. Suratman, Ketua Bidang Sosial dan Kemasyarakatan DKM Masjid Muhammad Ramadhan, 2 November 2016.

${ }^{27}$ Wawancara dengan Haris, Pengurus Harian DKM Masjid Muhammad Ramadhan, 2 November 2016.

${ }^{28}$ http:/ /jihaddandakwah.blogspot.co.id/2009/0 4/info-bedah-buku-dan-kajian-islam.html, (Diakses pada 1 November 2016). 
dukungan ISIS, kita akhirnya turun semua untuk merebut". 29

Setelah proses pengambilalihan masjid dari kepengurusan DKM lama, DKM yang baru bersama belasan ulama dan tokoh masyarakat di Kota Bekasi pada 20 Agustus 2014 bahkan mengadakan deklarasi penolakan paham ISIS dan menyatakan Masjid Muhammad Ramadhan sudah bersih dari pengaruh paham kelompok Negara Islam Irak dan Suriah. Deklarasi itu dihadiri tokoh masyarakat, Kepolisian dan militer setempat. Salah satu ulama setempat, KH. Abdul Hadi menjelaskan sejak 20 April masjid itu sudah diambil alih oleh Pemerintah Kota Bekasi. "Sudah bersih. Sekarang sudah tidak ada lagi. Saya tidak ingin ISIS kembali berkembang di sini," kata Abdul. Pendeklarasian ini menjadi penting, mengingat pertama kali kelompok ISIS melakukan deklarasi di Kota Bekasi, tempatnya dilakukan di masjid ini. tepatnya pada tanggal 15 Februari 2014 lalu, yang dipimpin Syamsuddin Uba dan dihadiri pula oleh tokoh ISIS lainnya sepertinya Bahrum Syah dan Said Sungkar. Mereka berdua merupakan alumni jihad Afghanistan.

"Saya sebagai warga Bekasi sangat keberatan. Justru yang melakukan deklarasi ISIS di masjid ini bukan berasal dari Bekasi. ISIS sudah lama beraktivitas di masjid ini," ujar $\mathrm{KH}$ Abdul Hadi. Abdul Hadi menjelaskan bahwa untuk memastikan masjid itu bersih dari ajaran paham ISIS, pihak Pemkot Bekasi mengubah total susunan Dewan Kemakmuran Masjid (DKM) atau pengurus masjid itu. Abdul Hadi juga mengatakan bahwa setelah masjid tersebut dikuasai oleh kelompok Syamsuddin Uba, aktivitas di dalam masjid semakin tertutup. Masjid hanya boleh dimasuki oleh kelompok mereka. Di luar kelompok mereka, dianggap kafir. "Semakin lama kelompok ini semakin banyak. Waktu itu, saya belum tahu

${ }^{29}$ Wawancara dengan Wahidin Hanbali, Wakil Ketua DKM Masjid Muhammad Ramadhan, 2 November 2016. ada ISIS. Saya baru sadar setelah ramai pemberitaan di televisi," ungkap Abdul Hadi. "Hari ini, kami membacakan deklarasi penolakan ISIS di Masjid Muhammad Ramadhan," imbuhnya.

Acara tersebut dihadiri Kapolresta Bekasi Kota Kombes Pol Priyo Widyanto, Kapolsek Bekasi Selatan Kompol Susilo Edy, Plh Danramil 01 Kranji Kapten Agus, pemerintahan setempat serta organisasi kemasyarakatan (ormas) seperti Forum Komunikasi Anak Betawi (Forkabi), Pemuda Pancasila, Forum Betawi Rempuk (FBR). Kini, Masjid Muhammad Ramadhan yang dibangun di atas lahan Fasos dan Fasum Pemkot Bekasi, dapat digunakan kembali oleh masyarakat luas tanpa dimonopoli satu kelompok tertentu. ${ }^{30}$

Setelah proses pengambilalihan oleh Pemkot dan penggantian kepengurusan DKM, Masjid Muhammad Ramadhan pun berganti status dari yang sebelumnya Masjid Jami' menjadi Masjid Raya Bekasi Selatan. Hal ini berarti Pemerintah Kota Bekasi turut bertanggung jawab dalam hal pendanaan Majid. Berdasarkan penjelasan Camat Bekasi Selatan, Abi Hurairah, "Atas dasar keinginan warga yang menginginkan Masjid Muhammad Ramadhan bisa digunakan untuk seluruh umat Islam, tidak ada lagi aliran yang keras yang memboikot jama'at". Lebih lanjut, ia mengatakan bahwa salah satu alasan kuat bagi Pemkot Bekasi dalam mengambil alih Masjid tersebut adalah karena keberadaan Masjid yang berdiri di atas tanah Fasos-Fasum (Fasilitias sosial - Fasilitas umum) milik Pemkot Bekasi.

\section{- Masjid Nurul Islam: Sebuah Wadah Terbuka}

Masjid Nurul Islam merupakan bagian dari Islamic Centre Kota Bekasi yang terletak di pusat bisnis daerah penyangga Ibu Kota Negara Indonesia. Tepatnya di Jl. Ahmad Yani

${ }^{30} \mathrm{http}: / /$ www.beritasatu.com/megapolitan/2040 73-ratusan-jemaah-masjid-muhammad-ramadhanbekasi-deklarasi-tolak-isis.html (Diakses pada 2 September 2016). 
No. 22 Kota Bekasi Jawa Barat. Masjid yang dirancang menjadi bagian integral dari pusat dakwah ini dibangun 25 tahun lalu saat Kota Bekasi masih menjadi bagian dari pemerintahan Kabupaten Bekasi. Kini, ketika Kota Bekasi telah berkembang pesat, Islamic Centre seakan menjadi oase di tengah belantara perkotaan yang pelan tapi pasti bergerak menjadi bagian dari perkembangan Megapolitan Jakarta.

Berada di jantung kota Bekasi yang sangat sibuk, Islamic Centre ini dikelilingi sejumlah pusat perbelanjaan ternama, sejumlah hotel berbintang, gedung olah raga, stasiun kereta api, hingga kantor pemerintahan. Tak ayal, kawasan yang dibangun dengan dana sumbangan masyarakat ini merupakan salah satu pusat dakwah Islam dengan kegiatan paling ramai di daerah perkotaan. Mulai hari Rabu 11 November 2015, Islamic Centre Bekasi berubah nama menjadi Islamic Centre KH. Noer Ali yang diresmikan oleh Walikota Bekasi, Rahmat Hidayat. ${ }^{31}$

Di samping berbagai kegiatan rutin seperti salat jumat, salat tarawih, dan salat hari raya, sejumlah gedung yang berada di komplek Masjid Nurul Islam dan Islamic Centre juga seringkali dimanfaatkan berbagai kegiatan lain. Seperti tabligh akbar, seminar, rapat ormas Islam, diklat instansi pemerintah, hingga resepsi pernikahan. Berbagai kegiatan tersebut diselenggarakan baik oleh Yayasan Nurul Islam sebagai pengelola, maupun diselenggarakan oleh lembaga lain seperti Majelis Ulama Indonesia (MUI), Ikatan Cendekiawan Muslim Indonesia (ICMI), Badan Koordinasi Majelis Taklim (BKMT), dan lain sebagainya. Adapun dalam Bidang Penelitian, Pengkajian, dan Pengembangan Dakwah, Yayayasan Nurul Islam mengadakan kegiatan berupa

${ }^{31}$ Sumber,

http://www.beritaekspres.com/2015/11/11/walikotabekasi-resmikan-nama-baru-islamic-center-bekasimenjadi-islamic-center-kh-noer-alie/ (Diakses pada 2 Oktober 2016).
Mudzakaroh Ulama, remaja dan wanita, studi keislaman, konsultasi keluarga Muslim, kepustakaan, dan seterusnya. ${ }^{32}$

Komitmennya terhadap keberagaman, adalah salah satu kunci keberhasilan Islamic Centre Bekasi dalam menjadi pusat pengembangan Islam yang didominasi oleh salah satu mazhab tertentu.Semenjak awal kehadirannya Islamic Centre Bekasi telah berkomitmen untuk tidak terpengaruh dengan perbedaan muamalah dan 'ubudiyah yang dapat menjadi pemicu perbedaan (kbilafah furu'iyah). Para pendirinya paham betul bahwa Bekasi yang merupakan daerah penyangga ibukota negara, memiliki heterogenitas yang kompleks dan perlu dipelihara secara baik. Selain itu, mereka juga meyakini bahwa perbedaan merupakan suatu rahmat dari Allah, yang jika dikelola dengan baik akan menjadi kekuatan yang luar biasa. Karenanya, Islamic Centre Bekasi bertekad untuk menjadi payung bagi seluruh aliran keyakinan tersebut.

Berangkat dari pemahaman tersebut, Islamic Centre Bekasi menjabarkannya dalam tiga visi-nya: ukhuwah atau persaudaraan, wihdah atau kesatuan, dan syi'ar. Visi tersebut kemudian dituangkan dalam 6 misi:

a. Mengupayakan pengamalan ajaran Islam dalam segala bentuk kegiatan;

b. Bertekad menjadi uswah hasanah di dalam menciptakan ukbuwah islamiyah;

c. Berupaya menghindari hal-hal yang bersifat khilafiyah furu'iyah di kalangan umat Islam;

d. Bahu membahu bersama saudara seiman untuk mencapai kejayaan Islam dan umatnya;

e. Mewujudkan terciptanya persatuan dan kesatuan umat Islam dan sesama umat beragama lainnya;

\footnotetext{
${ }^{32}$ Lebih jelasnya, lihat http://bimasislam.kemenag.go.id/post/berita/islamiccentre-bekasi-oase-islam-di-pusatkota\#sthash.V3ayQ0JX.dpuf, (Diakses pada 2 Oktober 2016).
} 
f. Menempatkan diri sebagai penggerak dan fasilitator kegiatan-kegiatan keislaman. ${ }^{33}$

Sifat keterbukaan dan kecairan Islamic Centre KH. Noer Ali dalam menerima berbagai aliran dan ideologi, sebagaimana dikemukakan di atas, membuatnya menjadi medan kontestasi antarberbagai organisasi masyarakat dalam menanamkan ideologinya. Karena memang, berbagai kegiatan dakwah di Islamic Centre tersebut, tidak hanya dinisiasi oleh Yayasan Nurul Islam sebagai pengelola resminya, namun berbagai kegiatan dakwah juga diselenggarakan oleh Majelis Ulama Indonesia (MUI), Ikatan Cendekiawan Muslim Indonesia (ICMI), Badan Koordinasi Majelis Taklim (BKMT). Tidak terkecuali ormas-ormas keagamaan yang memiliki orientasi ideologi radikal, seperti Hizbut Tahrir Indonesia (HTI) dan Jamaah Ansharut Tauhid (JAT).

HTI adalah salah satu ormas yang cukup aktif menggunakan Islamic Centre sebagai lokus penyebaran ideologi mereka. Baik berupa kajian rutin bulanan, maupun acara insidental seperti "Silaturahim Akbar Keluarga Besar HTI DPD II Kota Bekasi: Peran Ulama dalam Perubahan Besar Dunia Menuju Khilafah" pada 8 September 2013; dan "Daorah Dirasah Islamiyah: Hukum Menegakkan Khilafah Menurut Ulama Ahlus-Sunnah", pada 15 Maret 2015 lalu.

Dalam berbagai kegiatannya tersebut, HTI secara tegas dan konsisten selalu menyebarkan ideologi mereka dalam hal penegakan kbilafah Islam dan penentangan terhadap demokrasi dan ekonomi liberal. Bagi HTI, ide khilafah adalah sebuah kekuasaan yang menerapkan syariat Islam secara kaffah (menyeluruh). Karena itu, menjadi sebuah kebutuhan bagi umat Islam untuk mengangkat seorang khalifah yang akan memimpin Daulah Khilafah dan menerapkan syariat Islam secara kaffah. Karenanya, penegakan Daulah Khilafah

33 20 Islamic Centre Bekasi1993-2013: Meningkatkan Kemandirian Berkhidmah kepada Umat, h. 89. adalah adalah sebuah kewajiban, dan menjadi dosa besar atas setiap kelalaian dalam upaya penegakannya. $^{34}$

Dalam perjuangan dakwahnya, Hizbut Tahrir Indonesia lebih cenderung untuk merubah pemikiran ( ad' $^{\prime}$ ), yaitu dengan merubah kondisi masyarakat yang rusak menjadi masyarakat Islami. Hal ini dilakukan dengan mengubah ide-ide rusak yang ada menjadi ide-ide Islam, sehingga ide-ide tersebut menjadi opini di tengah-tengah masyarakat, serta menjadi persepsi bagi mereka untuk merealisasikan dan menerapkannya sesuai dengan tuntunan Islam demi terwujudnya masyarakat Islam yang kaffah. ${ }^{35}$

Selain itu, perjuangannya Hizbut Tahrir senantiasa berusaha mengikuti metode atau thariqah dakwah yang ditempuh Rasulullah sejak dari Makkah hingga tegaknya Negara Islam yang pertama di Madinah alMunawwarah. Karena itu, sebagaimana dilakukan oleh Rasulullah, Hizbut Tahrir melakukan perjuangan pemikiran, menentang berbagai paham, pemikiran dan ideologi yang rusak yang menjadi landasan dan dikembangkan oleh ideologi sekularisme, baik yang bercorak kapitalistik maupun sosialistik. Hizbut Tahrir dengan tegas mengungkap kesalahan dan kerusakan pemikiran-pemikiran tersebut, serta pertentangannya dengan Islam. Hizbut Tahrir juga menentang dengan keras konsep-konsep yang lahir dari paham sekulerisme seperti Demokrasi, Patriotisme, Sosialisme, dan Kapitalisme atau isme-isme lain. $^{36}$

Sejalan dengan upaya pemurnian pemikiran tersebut, Hizbut Tahrir juga

${ }^{34}$ Hizbut Tahrir Indonesia, Manifesto Hizbut Tabrir untuk Indonesia: Indonesia, Khilafah, dan Penyatuan Kembali Dunia Islam (2009), h. 14.

35 Wawancara dengan Muhammad Candra, Bendahara HTI DPD II Kota Bekasi, 6 November 2016.

${ }^{36}$ Hizbut Tahrir Indonesia, Manifesto Hiæbut Tahrir untuk Indonesia: Indonesia, Khilafah, dan Penyatuan Kembali Dunia Islam (2009), h. 68-69. 
melakukan perjuangan politik. Karena itu, Hizbut Tahrir mengoreksi, menentang, dan mengungkap kesalahan para penguasa serta mengungkap konspirasi mereka dengan negara-negara penjajah dan kelalaian mereka terhadap Islam dan urusan umat Islam. Dengan demikian, seluruh aktivitas Hizbut Tahrir bersifat politis, karena pengertian politik dalam Islam adalah memelihara urusan dan kepentingan umat dalam arti yang sesungguhnya. Di luar pemahaman tersebut, Islam hanya akan menjadi sekadar nasihat dan ajaran teoritis. Dengan demikian, wajar jika Hizbut Tahrir kemudian menjadi representasi umat Islam dalam perjuangan penerapan syariah Islam.

Sama halnya dengan HTI, kelompok JAT secara secara rutin mengadakan kajian tentang kekhalifahan di Islamic Centre Bekasi. 37 Tidak mengherankan bila dari beberapa laporan seperti yang dihimpun oleh Komunitas Intelijen Daerah (Kominda) Kota Bekasi, Islamic Centre Bekasi masuk dalam salah satu dari sedikitnya delapan masjid yang dijadikan tempat kegiatan penyebaran ideologi ISIS (Islamic State of Iraq and Syam) yang dimotori oleh Syamsudin Uba. ${ }^{38}$

\section{Modus Operandi Penyebaran Ideologi Radikal di Masjid}

Sebagai identitas formal dalam bentuk organisasi masyarakat (Ormas) keagamaan, Jamaah Ansharut Tauhid (JAT) dan Hizbut Tahrir Indonesia (HTI) tentu tidak dapat dilepaskan dari ideologinya dalam pengembangan dakwah mereka. Sehingga, penegasan ideologi yang khas dari masingmasing Ormas keagamaan tersebut menjadi

37 http:/ / www.cnnindonesia.com/nasional/2016 0304093954-74-115282/syamsudin-uba-saya-siarkan-

kekhilafahan-baghdadi-bukan-isis/

'Kemasukan'

38 "Delapan Masjid di Bekasi Diduga

https://m.tempo.co/read/news/2014/08/07/0645978

26/delapan-masjid-di-bekasi-diduga-kemasukan-isis

(Diakses pada 20 Februari 2016). sesuatu yang penting. Kondisi tersebut kemudian mendorong masing-masing Ormas keagamaan untuk merumuskan dan memanfaatkan berbagai instrumen dan strategi yang dipandang efektif.

Dalam kajian mengenai ideologi, modus operandi dilihat sebagai strategi penyebaran ideologi hingga dapat tersebar dan bekerja dalam mempengaruhi tingkah laku manusia. Pada akhirnya, strategi atau modus operandi ideologi tersebut dapat digunakan untuk meneguhkan kekuasaan. Dengan kata lain, pihak yang memiliki kuasa cenderung akan mempertahankan dominasinya terhadap pihak yang dikuasai. ${ }^{39}$

Dalam perspektif Louis Althusser, ideologi, dalam rangka untuk eksis, mengharuskan orang mereproduksi kondisi produksinya, dimana ia sendiri menjadi produk dan produsen sekaligus. Teori Althusser tersebut dikenal dengan nama appartus ideology. Ia membedakan apparatus ini ke dalam dua kategori, yaitu Repressive State Apparatus (RSA) dan Ideological State Apparatuses (ISA). Untuk kategori pertama meliputi pemerintah, polisi, tentara, jaksa, staf administrasi, dan sistem penjara. Sedangkan untuk yang kedua meliputi wilayah yang luas, seperti agama, pendidikan, keluarga, perusahaan, media, literatur, partai, dan sebagainya. Perbedaannya, jika RSA bekerja dengan kekerasan, maka ISA bekerja dengan ideologi. Namun demikian, meskipun ISA bekerja dengan ideologi tidak berarti tanpa kekerasan. $^{40}$

Berdasarkan kategori Althusser di atas, maka ISA memiliki relevansi untuk melihat bagaimana ideologi bekerja di masjid. Berbagai variabel terkait: situasi lingkungan dan transfer kognisi yang kondusif, muatan materi keagamaan, pengurus DKM dan penceramah

39 Lihat Bagus Takwim, Akar-Akar Ideologi: Pengantar Kajian Konsep Ideologi dari Plato hingga Bourdieu (Yogyakarta: Jalasutra, 2003), h. 127.

40 Louis Althusser, On The Reproduction of Capitalism Ideology and Ideological State Apparatuses (London: Verso, 1971), h. 233; 243-244. 
yang memiliki perspektif ideologis sebagai apparatus ideologinya dapat memberikan implikasi dalam penyebaran ideologi keagamaan tertentu, seperti ideologi radikal. Dengan kata lain, masjid sebagai basis keagamaan masyarakat menjadi salah satu wadah strategis bagi Ormas keagamaan untuk menyebarkan ideologi mereka, seperti terlihat pada kedua masjid yang menjadi objek bahasan di atas.

Dalam kasus Masjid Muhammad Ramadhan, situasi lingkungan sekitarnya yang merupakan perumahan Taman Galaxy, menjadikannya tempat terbuka bagi masyarakat kelas menengah-atas urban yang datang dari latar belakang variatif. Kondisi tersebut membuat Masjid Muhammad Ramamadhan rentan terhadap berbagai ideologi keagamaan yang bersifat ekspansif yang dibawa oleh penduduk pendatang. Hal ini terbukti dengan keterangan Wahidin Hanbali yang mengatakan bahwa kelompok JAT yang membawa ideologi radikal ke Masjid Muhammad Ramadhan adalah para pendatang, yang sebagian mereka tinggal perumahan sekitar masjid. ${ }^{41}$

Adapun strategi ekspansi yang dilakukan kelompok JAT di Masjid Muhammad Ramadhan adalah dengan cara lebih dahulu mempengaruhi pengurus DKM-nya. Ketika telah berhasi menguasai DKM, barulah kemudian membuat kegiatan-kegiatan penyebaran ideologinya. Pada tahap selanjutnya, ketika masjid telah benar-benar dikuasainya, barulah terjadi pergantian pengurus DKM dengan anggota kelompoknya. Strategi tersebut terlihat dengan digesernya pengurus DKM lama seperti Syuhada, Salimin, Sukandar Gozali ke Dewan Pembina yayasan, dan diganti dengan tokoh-tokoh yang berafiliasi dengan JAT, seperti Abu Jibril, Farid Okbah, dan Syamsudin Uba di Masjid Muhammad Ramadhan.

${ }^{41}$ Wawancara dengan Wahidin Hanbali, Wakil Ketua DKM Masjid Muhammad Ramadhan, 2 November 2016.
Pergantian pengurus DKM kepada orang-orang yang memiliki perspektif ideologi radikal dan berafiliasi dengan kelompok JAT, turut memberi dampak kepada ideologi masjid yang pada akhirnya memiliki afiliasi dengan kelompok JAT yang dipimpin Abu Bakar Ba'asyir. Afiliasi tersebut secara langsung turut mempengaruhi bentuk kegiatan taklim dan bedah buku yang rutin diadakan, maupun kegiatan khutbah Jum'at yang diisi oleh para khatib dari golongan mereka. Tidak heran bila materi utama yang sering sekali disampaikan adalah terkait dengan tema-tema yang mengkritisi sistem pemerintahan demokratis serta menggelorakan dakwah tauhid, dan jihad. Kontinuitas dan eksistensi penyebaran ideologi yang dianut JAT di Masjid Muhammad Ramadhan pada akhirnya membuatnya sangat populer di kalangan aktivis Islam radikal, baik yang berada di wilayah Jabodetabek maupun di luar Jabodetabek.

Menariknya, perlawanan terhadap ideologi radikal yang dibawa oleh JAT di Masjid Muhammad Ramadhan dilakukan dengan Repressive State Apparatus (RSA), melalui pengambilalihan dan penggantian DKM masjid yang dilakukan oleh Pemerintah Kota Bekasi dan dikawal kepolisian dan berbagai ormas yang anti JAT.

Berbeda dengan kasus Masjid Muhammad Ramadhan yang mana kelompok radikal melakukan intervensi kepada kegiatankegiatan di masjid melalui kepengurusan di DKM, Masjid Nurul Islam yang merupakan bagian dari Islamic Centtre Kota Bekasi sangat dinamis dalam kontestasi antarideologi moderat dan radikal. Kontestasi tersebut terjadi karena komitmen Islamic Centre untuk menjadi payung bagi semua aliran keyakinan dan ideologi keagamaan. Komitmen tersebut, tampak pada berbagai kegiatan dakwah di Islamic Centre tersebut, yang tidak hanya diselenggarakan oleh Yayasan Nurul Islam sebagai pengelola, tetapi juga kegiatan dakwah yang dilakukan oleh ormas-ormas. Tidak 
terkecuali ormas-ormas keislaman yang berideologi radikal, seperti HTI dan JAT.

HTI termasuk salah satu ormas yang cukup aktif menggunakan Islamic Centre sebagai lokus penyebaran ideologi mereka. Secara aktif, HTI memang aktif menjalin kerja sama dengan masjid-masjid. Misalnya tergambar dari wawancara dengan pengurus HTI Bekasi, berikut:

"Kami menjalin kerja sama yang dimulai dengan silaturahim dengan para Dewan Kemakmuran Masjid (DKM) dalam bentuk audiensi, memperkenalkan diri, dan tabligh keliling ketika bulan puasa. Syukur-syukur bisa melakukan kerja sama dalam bentuk khutbah Jum'at, kajian rutin, maupun kegiatan-kegiatan lainnya kita bisa diundang dan bisa diikutsertakan. Beberapa masjid sudah ada yang bekerja sama dengan kita, dalam dalam bentuk kajian seminggu sekali atau dua minggu sekali. Apa yang kita bahas? Ada beberapa yang umum, misalnya materi kontemporer yang lagi hangat, misalnya isu penistaan, atau kenaikan harga BBM. Ada juga yang memang khusus, kayak memang kajian rutin tentang iqtishodi atau sistem ekonomi Islam". ${ }^{42}$

Keterangan pengurus HTI di atas, sejalan dengan informasi yang diberikan oleh Wili Sutisna, seorang marbot Masjid Nurul Islam 1slamic Centre Bekasi, bahwa HTI memang sering datang untuk menyewa gedung, mengadakan pengajian, dan seminar. Dalam berbagai kegiatannya tersebut, HTI secara tegas dan konsisten selalu menyebarkan ideologi mereka dalam hal penegakan khilafah Islam dan penentangan terhadap demokrasi dan ekonomi liberal.

\section{Kesimpulan}

Masjid memiliki kaitan erat dengan fenomena sosial dan politik yang tengah berlangsung di masyarakat. Dengan demikian,

42 Wawancara dengan Muhammad Candra, Bendahara HTI DPD II Kota Bekasi, 6 November 2016. dapat dipahami jika masjid menjadi wadah bagi penyebaran ideologi dan paham keagamaan tertentu, tergantung pada siapa penguasa politik saat itu dan pada konteks sekarang siapa pengurus masjid tersebut.

Dalam konteks penelitian ini, beberapa hal yang menjadi kesimpulan adalah sebagai berikut:

Kedua masjid yang diteliti, yakni Masjid Muhammad Ramadhan dan Masjid Nurul Islami-Islamic Centre KH. Noer Ali Bekasi memperlihatkan terbukanya kesempatan yang cukup besar bagi berbagai kelompok keagamaan untuk menggunakan masjid sebagai tempat untuk menyemaikan ide-idenya dengan berbagai modus. Berbagai variabel seperti situasi lingkungan dan transfer kognisi yang kondusif, muatan materi keagamaan, pengurus DKM dan penceramah yang memiliki perspektif ideologis dapat memberikan implikasi dalam penyebaran ideologi keagamaan tertentu, seperti ideologi radikal. Dengan kata lain, masjid sebagai basis keagamaan masyarakat menjadi salah satu wadah strategis bagi ormas keagamaan untuk menyebarkan ideologi mereka, seperti terlihat pada kedua masjid yang menjadi objek bahasan di atas.

Modus operandi dan strategi ekspansi yang dilakukan kelompok radikal dalam penyebaran ideologinya di masjid dalam penelitian ini, berbeda antara satu masjid dengan masjid lainnya. Terlepas dari variannya, tidak diragukan lagi bahwa kesemuanya secara strategi awal yang dijalankan adalah dengan cara lebih dahulu mempengaruhi pengurus DKM-nya. Ketika telah berhasi menguasai DKM, barulah kemudian membuat kegiatankegiatan penyebaran ideologinya. Pada tahap selanjutnya, ketika masjid telah benar-benar dikuasainya, barulah terjadi pergantian pengurus DKM dengan anggota kelompoknya. Afiliasi DKM dengan organisasi tertentu memang sangat mempengaruhi bentuk kegiatan taklim dan bedah buku yang rutin 
diadakan, maupun kegiatan khutbah Jum'at yang diisi oleh para khatib dari golongan keagamaan mereka.

Penelitian ini telah memetakan gerakan Islam dan ideologi radikal yang meruyak ke masjid sebagai jantung umat Islam, khususnya di Kota Bekasi. Karenanya, sebagai rekomendasi, perlu kiranya dilakukan kontrol terhadap kebijakan dakwah di masjid, terutama dalam kerangka penguatan nilai-nilai kebangsaan Indonesia kita. Seperti promosi kesesuaian nilai Pancasila dan UUD 1945 dengan ajaran Islam. Pada akhirnya, masjid sebagai institusi Islam sudah seyogyanya menjadi corong terdepan untuk menyampaikan pesan-pesan perdamaian, kasih sayang, persatuan dan keadilan sosial. Peran ini hendaknya perlu direvitalisasi dan dikontekstualisasi agar cara dan strateginya dapat cocok dengan kebutuhan masyarakat Indonesia kontemporer yang ditakdirkan untuk majemuk dalam hal agama dan keyakinan, seperti Indonesia.

\section{Daftar Pustaka}

\section{Buku Teks}

Ahnaf, Mohammad Iqbal, dkk. Politik Lokal dan Konflik Keagamaan: Pilkada dan Struktur Kesempatan Politik dalam Konflik. Keagamaan di Sampang, Bekasi, dan Kupang (Yogyakarta: Center for Religious and Cross-cultural Studies/CRCS UGM, 2015).

Althusser, Louis, On The Reproduction of Capitalism Ideology and Ideological State Apparatuses (London: Verso, 1971.

al-Makassary, Ridwan, dkk., Benih-benih Islam Radikal di Masjid: Studi Kasus Jakarta dan Solo (Jakarta: CSRC UIN Syarif Hidayatullah Jakarta, 2010).

Bruinessen, Martin van. Contemporary Developments in Indonesian Islam: Explaining the "Conservative Turn" (Singapore: ISEAS, 2013).
Darwīsh, Ādil Muhammad, Al-Masjid fi alIslām wa Risālatubu fì al-Mujtama' alMu'āṣir (Kairo: Dār al-'Ilm, 1996).

Euben, Roxanne L., Enemy in the Mirror Islamic Fundamentalism and the Limits of Modern Rationalism (Princeton: Princeton University Press, 1999).

Farida, Anik, dkk., Transformasi Sosial Masjid dalam Pusaran Peradaban (Jakarta: Balai Litbang Agama Jakarta, 2013).

Hizbut Tahrir Indonesia, Manifesto Hizbut Tabrir untuk Indonesia: Indonesia, Kbilafah, dan Penyatuan Kembali Dunia Islam (2009).

Shihab, Quraish, Membumikan al-Qur'an (Bandung: Mizan, 1999).

Sopandi, Andi, Sejarah dan Budaya Kota Bekasi: Sebuah Catatan Perkembangan Sejarah dan Budaya Masyarakat Bekasi (Bekasi: Dinas Olahraga, Kebudayaan, dan Kepariwisataan Pemerintah Bekasi, 2009).

Takwim, Bagus, Akar-Akar Ideologi: Pengantar Kajian Konsep Ideologi dari Plato bingga Bourdieu (Yogyakarta: Jalasutra, 2003).

Wiktorowicz, Quinton, Radical Islam Rising: Muslim Extremism in the West (Lanham: Rowman and Littlefield Publishers, 2005).

\section{Jurnal Ilmiah}

Farahati, Abbasali, "The Mosque as the First Political-Ideological Base in the Islamic Society", Journal of Politics and Law, Vol. 4, No. 1, 2011, h. 146-152.

Heiduk, Felix, "Between a Rock and a Hard Place: Radical Islam in Post-Suharto Indonesia", International Journal of Conflict and Violence, Vol. 6, No. 1, 2012, h. 26-40.

Fealy, Greg, "Islamic Radicalism in Indonesia: The Faltering Revival?", Southeast Asian Affairs, 2004, h. 104-121.

Temby, Quinton, "Imagining an Islamic State in Indonesia: From Darul Islam to Jemaah Islamiyah", Indonesia, Vol. 89, 2010, h. 1-36.

Taufik, Zulfan, "Youth, Tarekat, and Religious Deradicalization in Indonesia: The 
Activism of Mahasiswa Ahlith Thariqah Al Mu'tabarah An Nahdliyyah (MATAN)", Proceeding The 9th International Graduate School and Scholars' Conference in Indonesia (Yogyakarta: Sekolah Pascasarjana UGM, 2017).

Bruinessen, Martin van., "Genealogies of Islamic Radicalism in Post-Suharto Indonesia", South East Asia Research, Vol. 10, No. 2, 2002, h. 117-154.

Sirozi, Muhammad, "The Intellectual Roots of Islamic Radicalism in Indonesia: Ja'far Umar Thalib of Laskar Jihad (Jihad Fighter) and His Educational Background", The Muslim World, Vol. 95, No. 1, 2005, h. 81-120.

Rozi, Syafwan, "Dari Islam Radikal ke Islam Pluralis: Geneologi Gerakan Paderi dan Pengaruhnya terhadap Islam Pluralis di Perbatasan Minangkabau", Masyarakat Indonesia, Vol. 41, No. 1, 2015, h. 15-27.

Syofyan, Donny, "Some Notes on Religious Radicalization and Terrorism in Indonesia", Islam Realitas: Journal of Islamic and Social Studies, Vol. 2, No. 2, 2016, h. 134-145.

Sunaryo, Agus, "Masjid dan Ideologisasi Radikalisme Islam: Menyoal Peran Masjid sebagai Media Transformasi Ideologi", Akademika, Vol. 22, No. 1, 2017, h. $225-$ 248.

\section{Wawancara}

Wawancara dengan H. Suratman, Ketua Bidang Sosial dan Kemasyarakatan DKM Masjid Muhammad Ramadhan, 2 November 2016.

Wawancara dengan Haris, Pengurus Harian DKM Masjid Muhammad Ramadhan, 2 November 2016.

Wawancara dengan Muhammad Candra, Bendahara HTI DPD II Kota Bekasi, 6 November 2016.

Wawancara dengan Muhammad Candra, Bendahara HTI DPD II Kota Bekasi, 6 November 2016.
Wawancara dengan Pak Ananto, Pengurus Yayasan Al-Anshor, 2 November 2016.

Wawancara dengan Wahidin Hanbali, Wakil Ketua DKM Masjid Muhammad Ramadhan, 2 November 2016.

Wawancara dengan Wahidin Hanbali, Wakil Ketua DKM Masjid Muhammad Ramadhan, 2 November 2016.

\section{Laporan}

IPDS BPS Kota Bekasi, Bekasi dalam Angka 2016 (Badan Pusat Statistik Kota Bekas, 2016).

Tahun, Marthen, Budi Asyhari-Afwan, dan Tim Data Center CRCS, Monograf Jawa Barat: Demografi Agama di Jawa Barat dan Anotasi Bibliografi (Work in Progress, 2015).

Badan Pusat Statistik, Kota Bekasi dalam Angka 2016 (Bekasi: BPS Kota Bekasi, 2016).

Alrasyid, Harun, dkk., Bekasi dari Masa ke Masa (Badan Pemberdaya Masyarakat Kabupaten Bekasi, 2006).

Pemerintah Kota Bekasi, Informasi Laporan Penyelenggaraan Pemerintaban Daerab Kota Bekasi Tahun 2014 (Pemerintah Kota Bekasi, Tahun Anggaran 2015).

\section{Website}

http://bimasislam.kemenag.go.id/post/berita /islamic-centre-bekasi-oase-islam-dipusat-kota\#sthash.V3ayQ0JX.dpuf, (Diakses pada 2 Oktober 2016).

http://jihaddandakwah.blogspot.co.id/2009/0 4/info-bedah-buku-dan-kajian-islam.html, (Diakses pada 1 November 2016).

http://metro.tempo.co/read/news/2014/08/ 07/064597826/delapan-masjid-di-bekasididuga-kemasukan-isis Diakses pada 1 Desember 2015.

http://nasional.sindonews.com/read/888364 /14/dukungan-kepada-isis-muncul-dibekasi-1407236192. Diakses pada 1 Desember 2015. 
http://news.liputan6.com/read/2087060/poli si-benarkan-ada-deklarasi-isis-di-masjid-almuhajirin-bekasi. Diakses pada 1 Desember 2015.

http://www.beritaekspres.com/2015/11/11/ walikota-bekasi-resmikan-nama-baruislamic-center-bekasi-menjadi-islamiccenter-kh-noer-alie/ (Diakses pada 2 Oktober 2016).

http://www.beritasatu.com/megapolitan/204 073-ratusan-jemaah-masjid-muhammadramadhan-bekasi-deklarasi-tolak-isis.html (Diakses pada 2 September 2016).

http://www.cnnindonesia.com/nasional/2016 0304093954-74-115282/syamsudin-ubasaya-siarkan-kekhilafahan-baghdadibukan-isis/

http://www.elhooda.net/2014/04/masjidmuhammad-ramadhan-diamankanpemkot-bekasi-dan-ormas-islam-karenasebarkan-ajaran-ekstrimisme/, (Diakses pada 20 November 2016).

http://www.jaringnews.com/politikperistiwa/umum/65489/ulama-masjidmuhammad-ramadhan-bekasi-sudahbersih-dari-isis\#sthash.hF5KtF9p.dpuf, (Diakses pada 2 September 2016).

http://www.muslimedianews.com/2014/04/a lhamdulillah-masjid-muhammadramadhan.html, (Diakses pada 20 November 2016).

http://www.voa-

islam.id/read/liberalism/2014/04/23/29 995/buntut-kisruh-masjid-m-ramadhanbekasi-majelis-talim-ngaji-di-parkiran/ (Diakses pada 28 November 2016).

https://m.tempo.co/read/news/2014/08/07 /064597826/delapan-masjid-di-bekasididuga-kemasukan-isis (Diakses pada 20 Februari 2016). 